\title{
Winter energy storage dynamics and cohort structure of young-of-the-year bluefish Pomatomus saltatrix off North Carolina
}

\author{
James W. Morley ${ }^{1, *}$, Jeffrey A. Buckel ${ }^{1}$, Thomas E. Lankford Jr. ${ }^{2}$ \\ ${ }^{1}$ Department of Zoology, Center for Marine Sciences and Technology, North Carolina State University, 303 College Circle, \\ Morehead City, North Carolina 28557, USA \\ ${ }^{2}$ Department of Biological Sciences and Center for Marine Science, University of North Carolina at Wilmington, \\ One Marvin Moss Lane, Wilmington, North Carolina 28409, USA
}

\begin{abstract}
The ecology of overwintering young-of-the-year bluefish Pomatomus saltatrix off North Carolina, USA, was examined for the 2001 and 2002 year-classes, to test the hypothesis that overwinter mortality affects the recruitment of summer-spawned bluefish. A trawling survey was conducted in Onslow Bay, North Carolina, from October 2001 to May 2002 and from September 2002 to June 2003 to determine bluefish abundance, cohort structure, energy density of white muscle and liver, and gut fullness. Up to 4 transects ranging from 0.4 to $16.1 \mathrm{~km}$ from shore were sampled monthly. Abundance of bluefish in Onslow Bay was high during the fall and declined with decreasing temperature in both years. Winter abundance was related to winter severity, with higher catches during the more mild winter of 2001 to 2002. At least 3 young-of-the-year cohorts were observed in both years. Gut fullness values generally followed temperature patterns, with reduced feeding during the winter. Energy reserves in white muscle and liver tissues peaked in November with larger fish having disproportionately more energy. However, by mid-winter there was little difference in energy reserves between the cohorts. These data suggest that larger fish deplete a greater portion of their energy stores as the season progresses while smaller fish deplete energy more slowly. Catch data show that summer-spawned bluefish survive the winter, but the magnitude of overwinter mortality remains uncertain.
\end{abstract}

KEY WORDS: Bluefish · Pomatomus saltatrix · North Carolina · Allometry $\cdot$ Lipids · Overwintering Energy reserves $\cdot$ Mortality

Resale or republication not permitted without written consent of the publisher

\section{INTRODUCTION}

Winter is a critical period for juvenile fishes in temperate latitudes. Overwinter mortality can cause a significant bottleneck in recruitment at the juvenile stage (Conover \& Ross 1982, Miranda \& Hubbard 1994, Hurst \& Conover 1998). Mortality during the winter is often size-selective, and smaller individuals experience higher mortality rates (see Sogard 1997). Negative size-selective overwinter mortality has been observed in many species including Atlantic silversides (Conover \& Ross 1982), yellow perch (Post \& Evans 1989), largemouth bass (Adams et al. 1982,
Miranda \& Hubbard 1994), roach (Griffiths \& Kirkwood 1995) and striped bass (Hurst \& Conover 1998, Sutton \& Ney 2001).

One hypothesis for this pattern of size-selective mortality is the more rapid depletion of energy reserves by smaller individuals. Because feeding ceases or is reduced at cold temperatures, overwintering fishes must depend on stored energy reserves to survive the winter (Foltz \& Norden 1977, Adams et al. 1982, Cunjak et al. 1987, Foy \& Paul 1999). Smaller individuals of a year-class have been shown to have disproportionately lower energy reserves (Schultz \& Conover 1997 , Post \& Parkinson 2001, Hurst \& Conover 2003) and a 
higher mass-specific metabolic rate (Post \& Lee 1996). This may result in smaller individuals of a year-class exhausting their energy stores more rapidly and approaching critical starvation levels sooner than larger members (Oliver et al. 1979, Sogard \& Olla 2000). Due to this size-selective pattern in overwinter mortality, individuals spawned later in the year may be less capable of enduring winter starvation.

A majority of overwinter field studies have been conducted either in freshwater systems or with marine species that have limited migratory capabilities during the winter. It is commonly thought that marine species capable of migrating to warmer waters do not experience strong selective pressure during the winter. However, the bluefish Pomatomus saltatrix, a subtropical species that undergoes large-scale seasonal migrations, has recently been hypothesized to experience negative sizeselective overwinter mortality (Conover et al. 2003).

Bluefish support a valuable recreational fishery on the US Atlantic coast, often being the most caught marine species annually (NOAA Fisheries 2005). However, the population has declined in abundance; between 1982 and 1996, annual recruitment of youngof-the-year (YOY) declined by over a factor of 5 (Fahay et al. 1999) and the recreational catch in recent years has been roughly half the values observed in the 1980s (NOAA Fisheries 2005). The reduction in population size may be explained by the recruitment dynamics of YOY bluefish. Lassiter (1962) collected scale samples from adult bluefish and determined the length of individuals at Age-1 using a back-calculation technique. This technique allows for examination of the length distribution of YOY that survived their first winter and the relative contribution that different sized YOY will ultimately make to the adult population. Lassiter's (1962) resulting back-calculated Age-1 length distribution was bimodal, indicating that 2 YOY cohorts contributed to the adult population. The 2 cohorts Lassiter (1962) identified are thought to be composed of fish spawned in the spring and summer based on larval sampling and recruitment dynamics of YOY bluefish in the Middle Atlantic Bight (Chiarella \& Conover 1990). A majority of YOY bluefish recruiting to the Middle Atlantic Bight (MAB) are thought to originate from either spawning during the spring in the South Atlantic Bight (SAB) with progeny transported north in the Gulf Stream (Kendall \& Walford 1979, Hare \& Cowen 1996), or summer spawning that occurs on the continental shelf of the MAB (Kendall \& Walford 1979, Smith et al. 1994). Summer spawning has recently been shown to be complex, consisting of multiple peaks (Taylor \& Able 2006) and 2 cohorts of summerspawned fish have been observed in addition to the larger spring-spawned cohort in the MAB (Able et al. 2003, Wilber et al. 2003).
Recent evidence suggests that summer-spawned bluefish are not contributing to the adult stock as much as they have in the past (Chiarella \& Conover 1990, Conover et al. 2003). This lack of contribution has occurred despite an increase in YOY abundance of the summer-spawned cohort along with a shift from spring-spawned bluefish dominating annual recruitment to summer-spawned fish dominating (Conover et al. 2003). While both cohorts are abundant in the MAB during the fall as they migrate south for their first winter (Munch \& Conover 2000, Conover et al. 2003), the adult population has been shown to be dominated by the spring cohort in recent years (Conover et al. 2003). This would suggest that in recent years the summer cohort is experiencing high mortality rates during the winter. Poor survival of summer-spawned bluefish coupled with their increase in relative abundance as YOY may explain the reduced state of the population.

Extensive research has been conducted on juvenile bluefish in the MAB during the summer and fall, but the ecology of juvenile bluefish has received very little attention in the $\mathrm{SAB}$, especially during the winter. We tested the hypothesis that negative size-selective overwinter mortality of YOY bluefish leads to poor survival of summer-spawned fish (i.e. fish $<200 \mathrm{~mm}$; Conover et al. 2003). We examined YOY bluefish collected in Onslow Bay monthly from fall through the spring for the 2001 and 2002 year-classes. Our objectives were to: (1) determine seasonal abundance patterns; (2) examine cohort structure; (3) examine energy storage dynamics to determine if smaller bluefish deplete energy reserves more rapidly as the winter progresses; (4) examine seasonal changes in feeding; and (5) test for negative size-selective mortality by comparing preand post-winter length-frequency distributions.

\section{MATERIALS AND METHODS}

Study site. Onslow Bay is located off the southern coast of North Carolina and is bounded by Cape Lookout to the north and Cape Fear to the south (Fig. 1). Depth increases from $\sim 7 \mathrm{~m}$ at $0.4 \mathrm{~km}$ from shore to $\sim 18 \mathrm{~m}$ at $16 \mathrm{~km}$ from shore. There is limited fisheryindependent data available for this region for the winter months. McBride et al. (1993) analyzed North Carolina winter oceanic trawl fishery data for the 1984 to 1985 season and found juvenile bluefish occurring throughout the winter. Additionally, the South Carolina Department of Natural Resources conducts the SEAMAP trawling survey, which samples from Cape Hatteras, North Carolina, to Florida. This survey routinely captured large numbers of juvenile bluefish off North Carolina in November and April 1989 to 2000; however, no long-term sampling has taken place dur- 


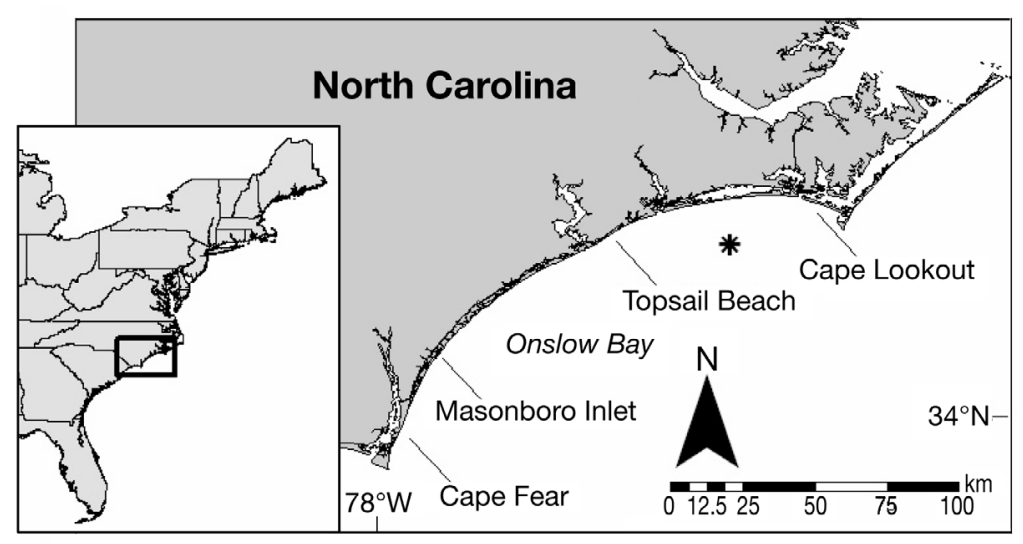

Fig. 1. Sampling area in Onslow Bay, North Carolina, showing locations of Cape Fear, Masonboro Inlet, Topsail Beach, and Cape Lookout transects. Transect lines are not to scale, sampling took place up to $16.1 \mathrm{~km}$ from shore. (*) Location of daily temperature logger mounted on the Suloid wreck in Onslow Bay, located $15 \mathrm{~km}$ from shore (Fig. 1) (Paula E. Whitfield, NOAA Beaufort Laboratory, Beaufort, North Carolina, unpubl. data). Daily temperature means were used to quantify differences in winter severity between the 2 winters.

An adjusted catch per unit effort (CPUE) value (see Munch 1997) was determined at each trawl station within each transect, month, and year:

$$
\ln (\text { CPUE })=\{\Sigma[\ln (\text { catch }+1)]\} \mathrm{n}^{-1}
$$

where catch $=$ number of juvenile bluefish caught in a given trawl and $n=$ number of tows at a given trawl station. These values were averaged within each month to develop an index of abundance for juvenile bluefish.

Cohort structure. Bluefish length frequency distributions were constructed for ing winter months (Anonymous 2000). Juvenile bluefish are not known to overwinter north of Cape Hatteras. Therefore, Onslow Bay is representative of the northern limit of the winter range and is a logical place to look for evidence of negative size-selective overwinter mortality.

Bluefish sampling. Monthly sampling was conducted from October 2001 through May 2002 and from September 2002 through June 2003 aboard the $21.3 \mathrm{~m}$ RV 'Cape Fear' in Onslow Bay. During the first season 4 transects were sampled monthly (Fig. 1). The Topsail Beach transect was removed after February 2002 due to unfavorable trawling bathymetry. Two transects were sampled each month during the 2002 to 2003 season (Masonboro Inlet and Cape Lookout). Initially each transect included 5 trawl stations located $0.8,1.6,3.2$, 8.0 and $16.1 \mathrm{~km}$ from shore. However, a $0.4 \mathrm{~km}$ station was added in December of 2001. During the first 4 mo of the 2001 to 2002 sampling season no bluefish were captured beyond $8 \mathrm{~km}$ from shore, so the $16.1 \mathrm{~km}$ station was removed after January 2002 and excluded from abundance analyses. Sampling was conducted using a spyder balloon bottom trawl with a $12 \mathrm{~m}$ wide head-rope, $1.83 \times 0.9 \mathrm{~m}(68 \mathrm{~kg})$ doors and a $1.27 \mathrm{~cm}$ mesh cod end. Two 20 min trawls were pulled parallel to shore at each station during daylight hours. Bluefish were also collected with supplemental sampling using hook and line, beach seine, and gill net in coastal waters of Onslow Bay; 8 bluefish were also obtained from the US Fish and Wildlife Service cooperative winter tagging bottom trawl cruise off North Carolina in January 2003. All bluefish were placed on ice and returned to the laboratory for processing. Water temperature throughout the overwintering period was recorded at $30 \mathrm{~min}$ intervals by a temperature logger each sampling time interval. During certain time intervals it was difficult to distinguish larger YOY from smaller Age-1+ bluefish because they can overlap in size with smaller Age-1 and Age-2 bluefish (Lassiter 1962, Salerno et al. 2001). In order to ensure that only YOY were examined, whole sagittal otoliths from larger bluefish of questionable age were inspected for annuli under a dissecting microscope. Whole otolith analysis has been shown to be an effective ageing technique for bluefish younger than Age-4 (Carmichael et al. 2002, Sipe \& Chittenden 2002). Bluefish typically lay down their first annulus in April of their second year (Barger 1990, P. J. Rudershausen et al. North Carolina State University, Morehead City, unpubl. data); therefore if an annulus was present on any individual caught during the fall or winter it was not included in the analyses. Likewise, if an individual caught during the spring had an annular mark that had not recently formed, or if 2 were present, it was not included. Otoliths from Age-1+ fish typically appeared much different from those of similar-sized YOY, with second-year growth forming as a second layer over and past the edge of the proximal surface.

In order to track each juvenile cohort through the overwintering period, it was necessary to objectively distinguish between them at each time interval using length distributions. First, the modal progression function of FiSAT II software was used on fall samples (Gayanilo et al. 2002). This program first uses the Bhattacharya method (Bhattacharya 1967) to fit normal curves to different modes in a length frequency distribution and then uses the NORMSEP function (Hasselblad 1966) to refine the parameter estimates of each curve. The antimodes between normal curves estimated in FiSAT were used as cut-off points for cohort 
assignments. FiSAT was used on trawl-caught bluefish from the October 18 to November 13 and the November 18 to December 6, 2001, time intervals for the 2001 year-class, and the November 3 to 25, 2002, interval for the 2002 year-class (see Figs. 3 \& 4). Cohort cut-off points estimated during the above time intervals were maintained throughout the remaining winter months assuming no growth. FiSAT was ineffective for early fall or spring samples due to low sample sizes, so 2 other techniques were employed. Cut-off points during time intervals preceding those that utilized FiSAT were back-calculated with a growth rate of $0.5 \mathrm{~mm} \mathrm{~d}^{-1}$ multiplied by the number of days that separated the 2 mean sampling dates. This fall growth rate is reasonable as YOY bluefish tagged in New Jersey grew at around $0.5 \mathrm{~mm} \mathrm{~d}^{-1}$ during September (Able et al. 2003). Cohort cut-off points following the winter had to be projected forward due to growth. Direct estimates of Age-1 bluefish growth by tagging has not been performed, so growth was estimated using Lassiter's (1962) von Bertalanffy growth functions. Lassiter (1962) generated separate growth functions for springand summer-spawned bluefish. The spring-spawned function was used for the Cohort 1/Cohort 2 cut-off point and the summer-spawned function was used for the Cohort 2/Cohort 3 cut-off (see Figs. $3 \& 4$ ). The growing season for Age-1 bluefish was assumed to start on April 1 as bluefish typically lay down their first annulus by April (Barger 1990, P. J. Rudershausen et al. unpubl. data). The von Bertalanffy function was used to estimate the growth increment from the Age-1 growth check (April 1) to the mean sampling date for each time interval.

Seasonal energy storage dynamics. Laboratory procedure: Juvenile bluefish were processed to quantify energy storage from October through June for both the 2001 and 2002 year-classes. Whole liver and a sample of epaxial white muscle were removed from each bluefish and individually frozen. A 4 to $5 \mathrm{~g}$ muscle sample was removed when the size of the specimen permitted; with smaller individuals the largest possible sample was obtained. After dissection, muscle samples were further processed by removing any attached red muscle or skin. Energy content of tissues was determined by gravimetric analysis following Schultz \& Conover (1997). Tissue samples were desiccated in a drying oven at $60^{\circ} \mathrm{C}$ until the weight stabilized ( 2 to $4 \mathrm{~d}$ ) and then neutral storage lipids were extracted in a Soxhlet extractor using petroleum ether as a solvent. Following extraction, tissue samples were combusted in a furnace at $450^{\circ} \mathrm{C}$ for $24 \mathrm{~h}$ to determine lean tissue and ash content. The total energy in the liver and energy density of wet muscle $\left(\mathrm{kJ} \mathrm{g}^{-1}\right)$ were calculated based on the energy density values of lipid (39.565 $\mathrm{kJ} \mathrm{g}^{-1}$ ) and protein $\left(20.097 \mathrm{~kJ} \mathrm{~g}^{-1}\right.$ ) reported in Brett \& Groves (1979).
Since phospholipids and carbohydrates are minor constituents of fish tissues (Love 1980), lean tissue weight was assumed to be protein.

Energy dynamics were analyzed in 3 ways to describe temporal and size-based patterns in body weight (whole wet weight of fish minus stomach contents), muscle energy density and liver energy. Due to changes in sample length distributions among dates, ANCOVA was used to address temporal changes for each variable. To determine size-based energetic advantages, allometric analysis was used for body weight, and liver lipid and protein weight. Allometric analyses could not be used to assess size-based patterns in muscle energy, as energy content from only a subsample of white muscle was determined. Therefore, mean values of muscle energy density for each cohort throughout the overwinter period were also examined. Both ANCOVA and allometric analyses are described in detail below. For both analyses, the larger-bodied cohort (Cohort 1, see 'Results') was excluded due to insufficient samples throughout the year. Also, only time intervals with a range in bluefish lengths of $60 \mathrm{~mm}$ or more and a sample size of at least 15 fish were examined (Table 1). Both trawl- and nontrawl-caught bluefish were used. Allometric relationships were examined to ensure that no biphasic patterns were present (Post \& Parkinson 2001). Statistical analyses were performed using STATISTICA ver. 6.1 (Statsoft 2004).

Analyses of temporal dynamics: Using fish length as a covariate on a ln-ln transformed scale, the lengthadjusted mean of each dependent variable was compared across time intervals using ANCOVA. Planned comparisons were used to test for significant differences between consecutive time intervals within each ANCOVA model, and significance levels were adjusted within each model using the standard Bonferroni technique $\left(\alpha \times\right.$ no. of tests $\left.{ }^{-1}\right)$. In addition to comparing time intervals within a year, inter-annual comparisons (2001 vs. 2002 year-classes) were made with pre- and post-winter liver energy, muscle energy density, and body weight. Inter-annual comparison ANCOVA models were generated for each dependent variable; each included November and April time intervals for each year-class. Planned comparisons were used to test for differences between year classes for both months. All but 3 of the above ANCOVA models failed to meet the assumption for homogeneity of slopes across time intervals. Therefore separate slope ANCOVA models were used with the exception of liver energy for both year-classes and body weight for the 2001 year-class, which had homogenous slopes.

Analysis of seasonal allometries: Temporal changes in size-based advantages were examined using allo- 
Table 1. Pomatomus saltatrix. Seasonal energy storage dynamics. Mean and standard deviation for length, along with minimum and maximum values, and sample size for bluefish used for allometric analyses and ANCOVA models during each time interval. Included is the adjusted mean length for each ANCOVA model

\begin{tabular}{|c|c|c|c|c|c|}
\hline $\begin{array}{l}\text { Time interval } \\
\text { (mm/dd/yy) }\end{array}$ & Mean & $\mathrm{SD}$ & Min. & Max. & $\mathrm{n}$ \\
\hline \multicolumn{6}{|l|}{ Body weight } \\
\hline 2001 year-class & \multicolumn{5}{|c|}{ ANCOVA adjusted length $=183.4 \mathrm{~mm}$} \\
\hline 10/18-11/13/01 & 198.0 & 12.737 & 158 & 227 & 75 \\
\hline 11/18-12/6/01 & 179.0 & 24.553 & 127 & 230 & 98 \\
\hline 02/03-02/13/02 & 175.9 & 31.191 & 124 & 228 & 92 \\
\hline 04/02-04/08/02 & 170.7 & 20.131 & 135 & 227 & 55 \\
\hline 04/30-05/07/02 & 201.2 & 21.510 & 153 & 236 & 50 \\
\hline 06/09-06/20/02 & 219.1 & 20.673 & 186 & 249 & 17 \\
\hline 2002 year-class & \multicolumn{5}{|c|}{ ANCOVA adjusted length $=184.8 \mathrm{~mm}$} \\
\hline 11/03-11/25/02 & 193.0 & 32.150 & 136 & 263 & 147 \\
\hline $12 / 12-12 / 17 / 02$ & 157.1 & 25.807 & 106 & 242 & 95 \\
\hline $03 / 22-04 / 14 / 03$ & 202.3 & 42.219 & 131 & 261 & 69 \\
\hline $04 / 24-05 / 21 / 03$ & 230.0 & 39.953 & 155 & 271 & 22 \\
\hline $05 / 29-06 / 22 / 03$ & 209.3 & 32.075 & 176 & 283 & 27 \\
\hline \multicolumn{6}{|c|}{ Liver allometries and total energy } \\
\hline 2001 year-class & \multicolumn{5}{|c|}{ ANCOVA adjusted length $=184.7 \mathrm{~mm}$} \\
\hline 10/18-11/13/01 & 198.4 & 14.805 & 158 & 225 & 41 \\
\hline 11/18-12/06/01 & 174.6 & 25.752 & 127 & 218 & 53 \\
\hline $02 / 03-02 / 13 / 02$ & 172.4 & 30.869 & 124 & 225 & 46 \\
\hline 04/02-04/08/02 & 175.5 & 21.374 & 135 & 227 & 38 \\
\hline 04/30-05/07/02 & 202.2 & 21.806 & 153 & 236 & 47 \\
\hline 06/09-06/20/02 & 219.1 & 20.673 & 186 & 249 & 17 \\
\hline 2002 year-class & \multicolumn{5}{|c|}{ ANCOVA adjusted length $=187.7 \mathrm{~mm}$} \\
\hline 11/03-11/25/02 & 182.7 & 39.301 & 136 & 263 & 40 \\
\hline $12 / 12-12 / 17 / 02$ & 165.1 & 31.502 & 106 & 242 & 48 \\
\hline $03 / 22-04 / 14 / 03$ & 196.2 & 41.774 & 131 & 261 & 60 \\
\hline $04 / 24-05 / 21 / 03$ & 230.0 & 39.953 & 155 & 271 & 22 \\
\hline 05/29-06/22/03 & 213.8 & 33.614 & 176 & 283 & 30 \\
\hline \multicolumn{6}{|c|}{ Muscle energy density } \\
\hline 2001 year-class & \multicolumn{5}{|c|}{ ANCOVA adjusted length $=185.8 \mathrm{~mm}$} \\
\hline 10/18-11/13/01 & 198.8 & 14.022 & 158 & 225 & 43 \\
\hline 11/18-12/06/01 & 174.5 & 26.522 & 127 & 230 & 55 \\
\hline $02 / 03-02 / 13 / 02$ & 172.5 & 30.631 & 124 & 225 & 35 \\
\hline $04 / 02-04 / 08 / 02$ & 176.4 & 21.651 & 135 & 227 & 37 \\
\hline $04 / 30-05 / 07 / 02$ & 203.5 & 21.336 & 153 & 236 & 45 \\
\hline $06 / 09-06 / 20 / 02$ & 219.1 & 20.673 & 186 & 249 & 17 \\
\hline 2002 year-class & \multicolumn{5}{|c|}{ ANCOVA adjusted length $=188.3 \mathrm{~mm}$} \\
\hline 11/03-11/25/02 & 184.6 & 40.690 & 136 & 263 & 41 \\
\hline $12 / 12-12 / 17 / 02$ & 165.0 & 31.497 & 106 & 242 & 48 \\
\hline 03/22-04/14/03 & 196.2 & 41.774 & 131 & 261 & 60 \\
\hline $04 / 24-05 / 21 / 03$ & 230.0 & 39.953 & 155 & 271 & 22 \\
\hline $05 / 29-06 / 22 / 03$ & 215.9 & 35.123 & 176 & 283 & 31 \\
\hline
\end{tabular}

metric analyses. The allometric relationship between length $(L)$ and weight $(W)$ is described by the function:

$$
W=\mathrm{a} L^{\mathrm{b}}
$$

where $\mathrm{a}$ and $\mathrm{b}$ are constants. This function is used to describe the weight of the entire organism, organs, or tissue components such as lipid and protein. The above equation can be linearized with a log transformation and analyzed with linear regression:

$$
\ln (W)=\ln (\mathrm{a})+\mathrm{b}[\ln (L)]
$$

Growth in weight is termed isometric when $\mathrm{b}=3$, as body form does not change with respect to length. When the slope of the function is not equal to 3, weight is allometric to length. Hyperallometric growth ( $b>3$ ) results in higher weight for a given length with longer individuals having disproportionately higher weight. Conversely, hypoallometric growth $(\mathrm{b}<3$ ) results in lower weight for a given length with longer individuals having relatively less weight. Bluefish body weight, liver lipid weight, and liver protein weight were each related to fork length using ln-ln transformed linear regression for each time interval. Slopes within each season and tissue type were tested against the null hypothesis of isometric growth using 2-tailed $t$-tests, with Bonferroni-adjusted significance levels $(\alpha \times$ no. of tests $^{-1}$ ).

Winter feeding dynamics. Stomachs were removed from trawl-caught bluefish and fixed in 10\% buffered formalin. Prey were removed from stomachs, blotted dry and weighed to the nearest $0.001 \mathrm{~g}$. Gut fullness was determined as the weight of the stomach contents divided by the weight of the bluefish without prey. The influence of bluefish length on winter feeding was examined using 2 time intervals for each year-class. Trawl-caught fish from December and February were used for the 2001 year-class and November and December for the 2002 year-class. These months were chosen because of high sample sizes and broad length distributions. These months also allowed the examination of the effect of bluefish size on feeding during a warmer fall month $\left(>16^{\circ} \mathrm{C}\right)$ and a cooler winter month $\left(<13^{\circ} \mathrm{C}\right)$. Bluefish in each time interval were separated into length bins of 101-150, 151-200, and 201-250 mm. Because gut fullness values could not be transformed to meet assumptions of parametric statistics, differences in gut fullness between bins were analyzed using Kruskal-Wallis ANOVA by ranks.

Negative size-selective mortality. Negative sizeselective mortality was examined using the cohort of smallest body size (Cohort 3, see 'Results') by comparing length frequency distributions before and after the winter. Assuming no growth or emigration during the winter, an increase in the mean length and a decrease in the coefficient of variation for a cohort of fish between the 2 sampling intervals indicates selective mortality of smaller individuals (Ricker 1969, Post \& Evans 1989). This analysis was restricted to the 2002 year-class because the 2001 year-class lacked a high sample size of Cohort 3 in pre- and post-winter collections. The December and early-spring (March 22 to April 14) time intervals were compared for the 2002 year-class using a $t$-test (mean) and $F$-test (variance). 


\section{RESULTS}

\section{Seasonal abundance and cohort structure}

During the 2001 to 2002 sampling season, 233 trawls were completed capturing 873 bluefish from the 2001 year-class. A total of 181 trawls were performed during 2002 to 2003 capturing 848 bluefish from the 2002 year-class. Bluefish CPUE values were highest nearshore, as $95.5 \%$ of bluefish were captured within $1.6 \mathrm{~km}$ of shore. Temperature differences between the 2 sampling seasons were pronounced, with the winter of 2002 to 2003 being more severe. Water temperatures were on average $2.2^{\circ} \mathrm{C}$ colder in 2002 to 2003 from December 1 through March $31\left(3.5^{\circ} \mathrm{C}\right.$ if March is excluded), than the preceding winter (Fig. 2). Abundance of the 2001 year-class was highest in October and declined concomitant with declining temperature over the next 3 mo (Fig. 2a). In February temperature increased slightly and the CPUE of bluefish increased greatly; however, by March bluefish catch had dropped to zero despite relatively mild temperatures (Fig. 2a). Temperature increased over the following 2 mo along with bluefish CPUE (Fig. 2a). Abundance patterns of bluefish differed during the more severe

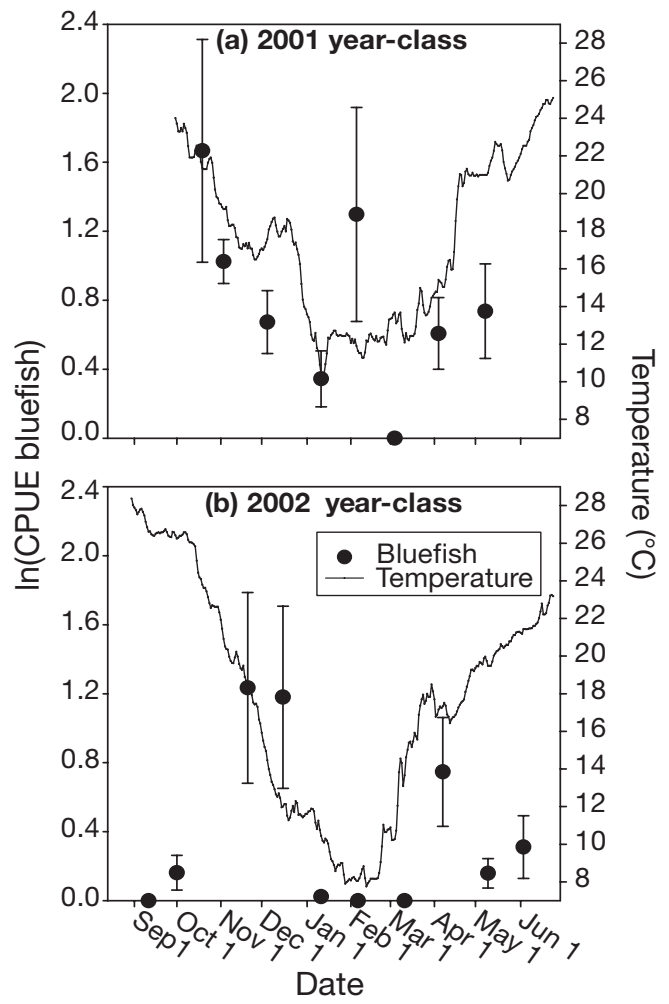

Fig. 2. Pomatomus saltatrix. Monthly mean $\ln (\mathrm{CPUE})( \pm \mathrm{SE})$ for young-of-the-year (YOY) bluefish captured by bottom trawl in Onslow Bay, along with mean daily water temperature for (a) the 2001 year-class, and (b) the 2002 year-class. Note separate $y$-axes for each variable winter of 2002 to 2003. Catches were highest during November and December, however only one member of the 2002 year-class was captured in Onslow Bay during January, February, and March (Fig. 2b). Following the winter, bluefish catches were high in April, but dropped to moderate levels in May and June.

Three juvenile cohorts were commonly caught during both years of the study (Figs. $3 \& 4$ ). Cohorts were labeled 1, 2, and 3 in order of decreasing fish length. Based on hook-and-line catches, Cohort 1 and larger members of Cohort 2 were present during the early fall but occurred primarily in nearshore estuarine waters, as trawl catches on the continental shelf were low (Figs. 3a \& 4a). By mid October to early November Cohort 2 dominated trawl catches (Figs. 3b \& 4b). By November of each year, length distributions became tri-modal, as a third cohort made up of smaller fish was commonly caught (Figs. 3c \& 4b). In the winter and the following spring, trawl catches of Cohort 1 were typically very low, but hook-and-line catches revealed their presence during the spring in nearshore waters such as inlets (Figs. 3i \& 4e,g). Cohort 3 dominated catches during the winter and early spring for the 2001 year-class (Fig. 3e-h). Very few samples were obtained during the winter of 2002 to 2003, but the third cohort dominated catches in late autumn and early spring (Fig. 4c,e). During early May of 2002, a fourth cohort consisting of smaller fish was captured (Fig. 3h). Otolith analyses indicated that individuals from this fourth cohort were members of the 2001 year-class.

\section{Seasonal energy storage dynamics}

Muscle energy density by cohort

Energy levels in muscle tissue reached peak values by November or December and energy density was highest in Cohort 1 and lowest in Cohort 3 (Fig. 5). During both overwintering periods, the greatest difference in energy storage between the cohorts occurred during the fall. During the winter, the difference in energy density between cohorts diminished as energy was depleted more rapidly in cohorts consisting of larger bluefish. By February all 3 cohorts had similar values for muscle energy storage for the 2001 year-class; this pattern persisted through May (Fig. 5a). Similarly, the inter-cohort difference in energy storage for the 2002 year-class declined dramatically from November to January (Fig. 5b). However, the 2002 year-class differed from the 2001 yearclass in the early spring. In April 2003 there was a substantial size-based pattern in energy density; this was due to the lower energy levels of Cohort 3 and higher levels in Cohort 1 compared to the preceding year (Fig. 5b). 
Analyses of temporal dynamics

After adjustment to a common fish length using ANCOVA, juvenile bluefish from Cohorts 2 and 3 combined exhibited significant temporal changes in liver energy, muscle energy density, and body weight for both year-classes (Table 2). Each variable reached peak levels during the fall and exhibited significant declines during the winter (Fig. 6). Following the winter, body weight recovered during the spring in both years, but increases were only significant for the 2001 year-class. Muscle energy stayed fairly stable after the initial decline in February during the winter of 2001 to 2002 (Fig. 6a). However, the 2002 year-class had an increase in muscle energy density following the decline in winter (Fig. 6b). Liver energy exhibited further decline during the early spring for the 2001 year-class (Fig. 6a), but the 2002 year-class remained stable after the winter months (Fig. 6b).

After adjusting to a common length between yearclasses using ANCOVA, bluefish from the 2001 yearclass had significantly higher muscle energy levels in
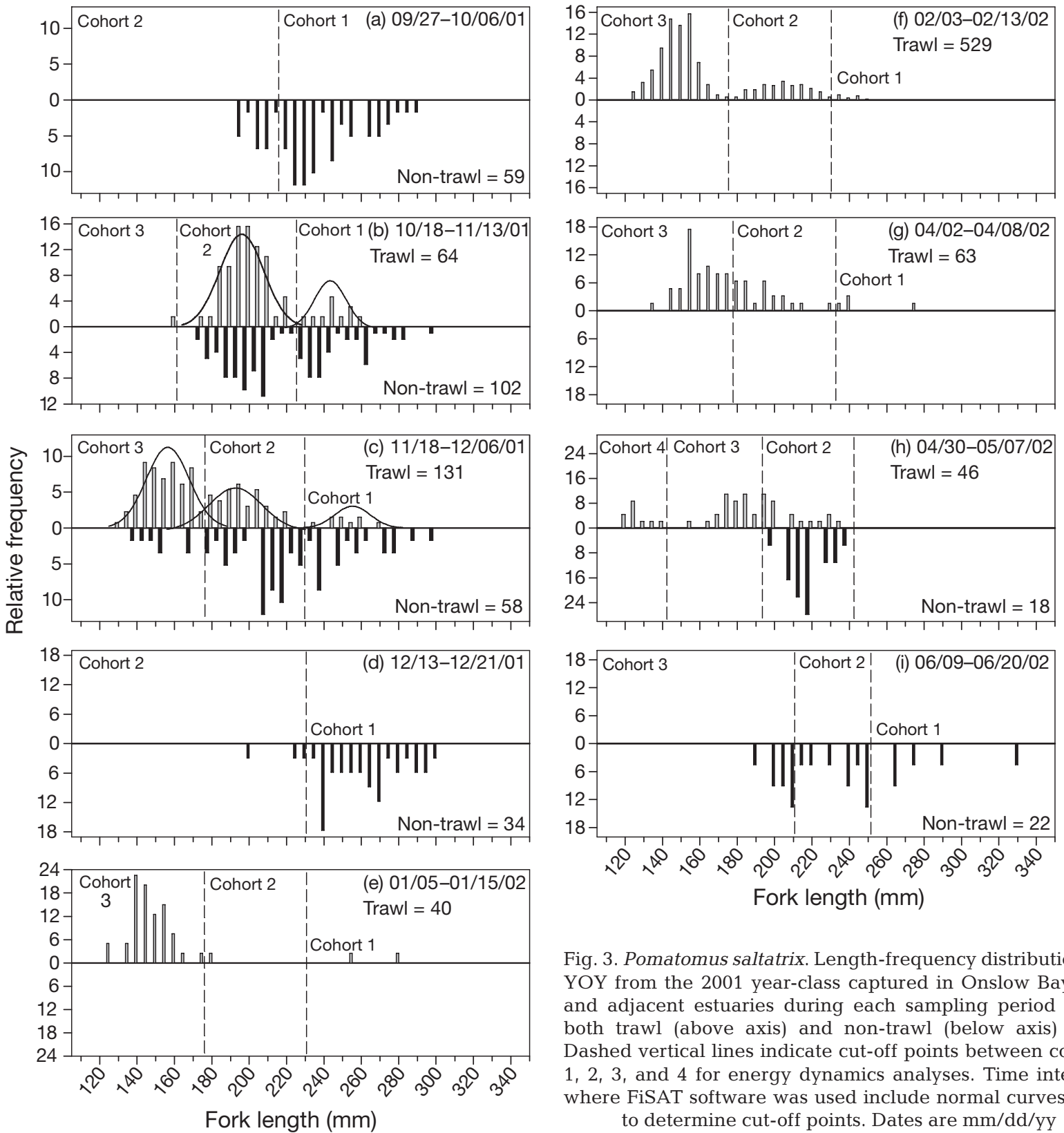

Fig. 3. Pomatomus saltatrix. Length-frequency distributions of YOY from the 2001 year-class captured in Onslow Bay, NC and adjacent estuaries during each sampling period using both trawl (above axis) and non-trawl (below axis) gear. Dashed vertical lines indicate cut-off points between cohorts $1,2,3$, and 4 for energy dynamics analyses. Time intervals where FiSAT software was used include normal curves used to determine cut-off points. Dates are $\mathrm{mm} / \mathrm{dd} / \mathrm{yy}$ 

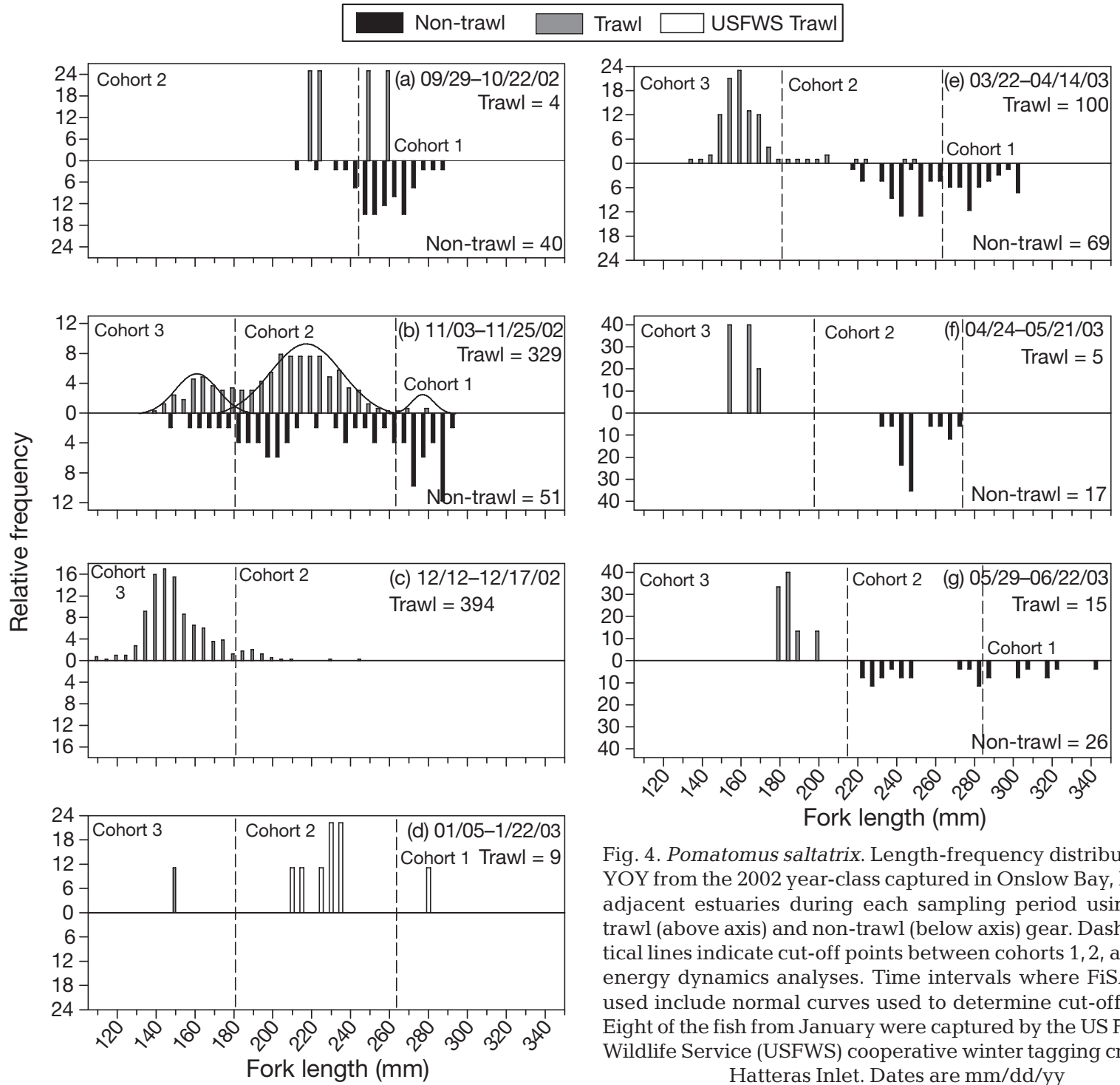

Fork length $(\mathrm{mm})$

Fig. 4. Pomatomus saltatrix. Length-frequency distributions of YOY from the 2002 year-class captured in Onslow Bay, NC and adjacent estuaries during each sampling period using both trawl (above axis) and non-trawl (below axis) gear. Dashed vertical lines indicate cut-off points between cohorts 1,2, and 3 for energy dynamics analyses. Time intervals where FiSAT was used include normal curves used to determine cut-off points. Eight of the fish from January were captured by the US Fish and Wildlife Service (USFWS) cooperative winter tagging cruise off Hatteras Inlet. Dates are mm/dd/yy

November and April than the 2002 year-class (November: $\mathrm{df}=1, F=37.441, \mathrm{p}<0.001$; April: $\mathrm{df}=1$, $F=16.401, \mathrm{p}<0.001)$. Differences between yearclasses in November liver energy were not significant $(\mathrm{df}=1, F=0.010, \mathrm{p}=0.920)$, however the 2001 yearclass had greater liver energy levels in April ( $\mathrm{df}=1$, $F=12.220, \mathrm{p}<0.001$ ). Conversely, comparing body weight of the 2 year-classes revealed that the 2002 year-class had a higher pre- and post-winter lengthadjusted body weight, but differences were only significant during the fall (November: $\mathrm{df}=1, F=15.473$, $\mathrm{p}<0.001$; April: $\mathrm{df}=1, F=3.093, \mathrm{p}=0.079$ ). However, these contradictory results for body weight are likely to be a result of body weight peaking earlier than the time interval that was used for the 2001 year-class (Fig. 6a).

\section{Analyses of seasonal allometries}

Seasonal allometries for body weight were hyperallometric throughout the overwinter period for both year-classes. However, values were only significant during the late fall and winter for the 2001 year-class (Fig. 7a) and all time intervals but May for the 2002 year-class (Fig. 7b). Liver lipid and protein weight allometries exhibited much greater seasonal change than body weight. Additionally, variations in liver lipid and protein weight allometries were much higher than for body weight, which resulted in only 1 time interval with allometries significantly different from isometric growth. There was a trend for hyperallometric relationships for liver lipid and protein weight during the fall of both years followed by declining values during 


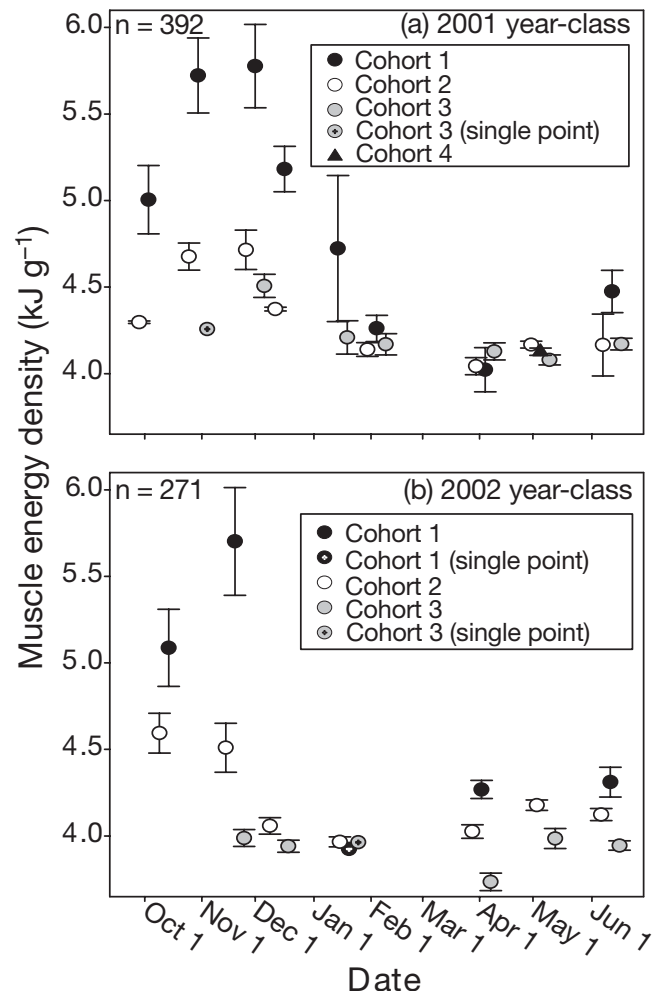

Fig. 5. Pomatomus saltatrix. Mean $( \pm \mathrm{SE})$ wet muscle energy density by cohort of YOY captured in Onslow Bay, during each time interval for (a) the 2001 year-class and (b) the 2002 year-class

the winter (Fig. 7). The 2001 year-class exhibited stable allometries for liver constituents after the initial winter decline until June, when slopes increased (Fig. 7a). For the 2002 to 2003 season, liver lipid was significantly hypoallometric following winter, and then increased in May. Liver protein weight never fell below isometry for the 2002 year-class (Fig. 7b). In general, larger fish had disproportionately greater

Table 2. Pomatomus saltatrix. Analyses of covariance models for the seasonal energy storage and body weight of the 2001 and 2002 year-classes of bluefish with $\ln$ (fork length) as covariate. Only Cohorts 2 and 3 were included in the analyses

\begin{tabular}{|lllrrrc|}
\hline Dependent variable & Effect & df & SS & $F$ & $\mathrm{p}$ \\
\hline 2001 year-class & & & & & \\
ln(liver energy) & Month & 5 & 10.270 & 6.80 & $<0.001$ \\
$\ln$ (muscle energy) & Month & 5 & 0.131 & 5.17 & $<0.001$ \\
$\ln$ (body weight) & Month & 5 & 1.200 & 44.00 & $<0.01$ \\
2002 year-class & & & & & \\
ln(liver energy) & Month & 4 & 14.080 & 22.30 & $<0.001$ \\
$\ln$ (muscle energy) & Month & 4 & 0.066 & 5.03 & 0.001 \\
$\ln$ (body weight) & Month & 4 & 0.100 & 3.00 & 0.022 \\
\hline
\end{tabular}

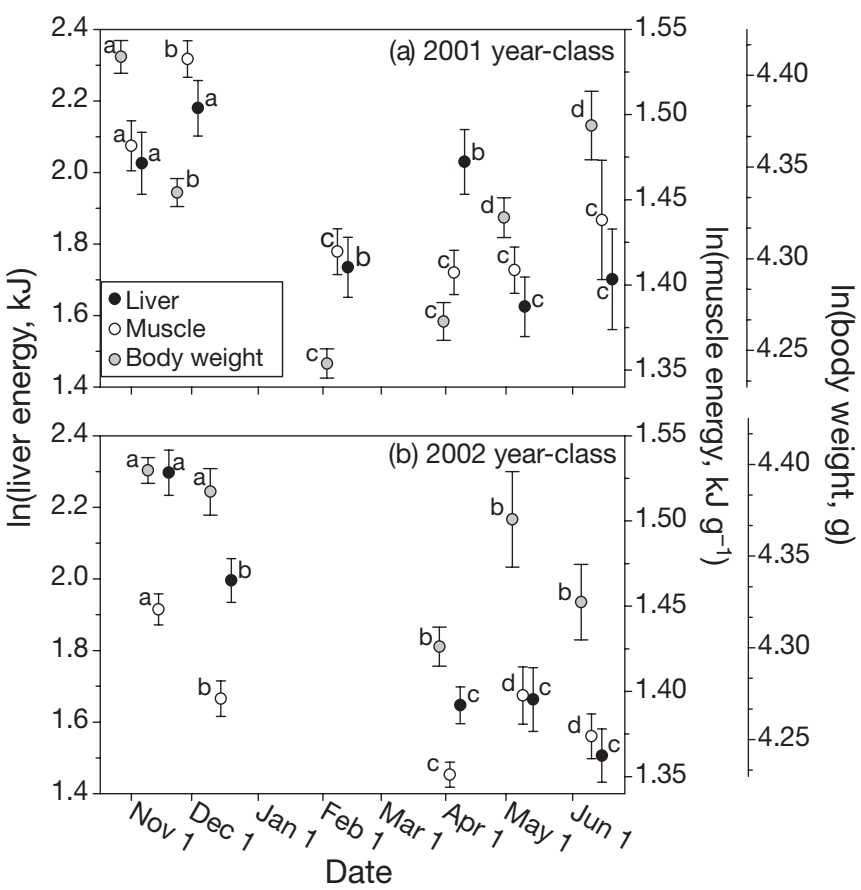

Fig. 6. Pomatomus saltatrix. Length-adjusted means $( \pm \mathrm{SE})$ for liver energy, muscle energy density, and body weight of YOY from Cohorts 2 and 3 combined for (a) the 2001 year-class, and (b) the 2002 year-class. Bluefish were captured in Onslow Bay. Note separate $y$-axis for each dependent variable. Like letters within $(a, b, c, d)$ each year-class and variable indicate no significant difference between adjacent time intervals, determined with planned comparisons. Note that each yearclass is adjusted to a different length so comparing values between year-classes is not appropriate

body weight throughout the sampling period. Also, larger fish had advantages in liver lipid and protein weight during the fall. However, during the winter and early spring, smaller fish had greater liver lipid reserves in both years, and greater protein content for one of the two years.

\section{Winter feeding dynamics}

Seasonal trends in gut fullness generally followed the pattern of temperature changes throughout the overwinter period for the 2001 year-class, with peak values in November (Fig. 8a). However, gut fullness values in April were an exception, with low values despite temperature increases. For the 2002 year-class, gut fullness also peaked in November, but gut fullness values were moderate in the remaining months with no distinct relation with temperature (Fig. 8b). Kruskal-Wallis ANOVA revealed no significant effect of bluefish length on gut fullness during December of $2001(\mathrm{df}=2, \mathrm{n}=81, H=4.583, \mathrm{p}=0.101)$. However, length did have a significant effect on gut fullness for 


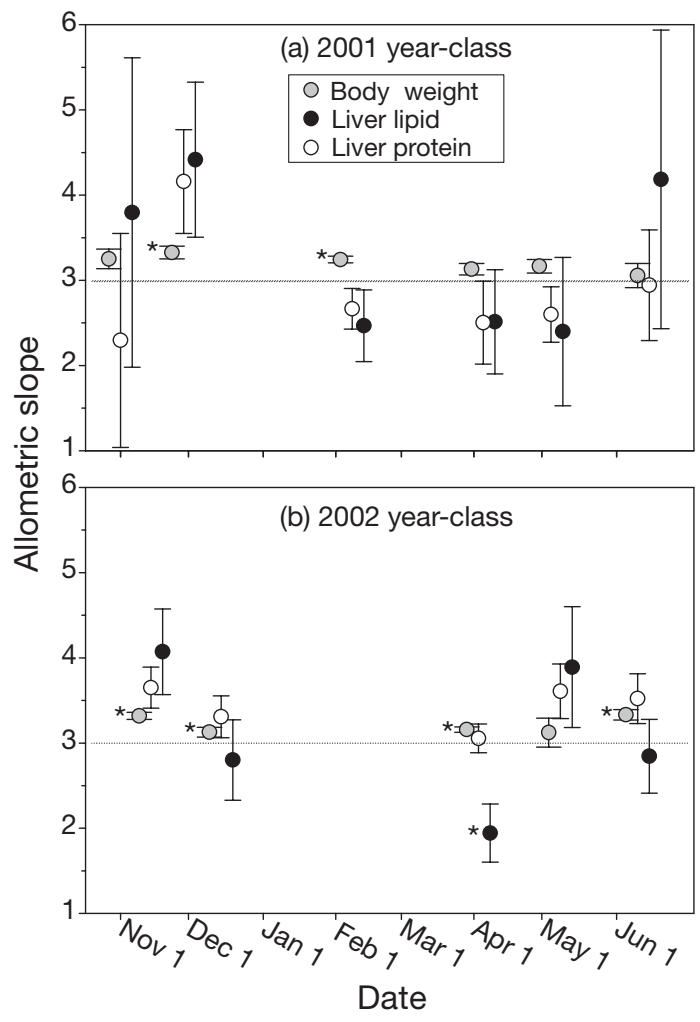

Fig. 7. Pomatomus saltatrix. Allometric slopes $( \pm$ SE) for YOY from Cohorts 1 and 2 combined for body weight, liver lipid weight, and liver protein weight during each time interval for (a) the 2001 year-class, and (b) the 2002 year-class. Bluefish were captured in Onslow Bay. *: Time intervals with a slope significantly different from 3 (dotted line) the 2001 year-class in February ( $\mathrm{df}=2, \mathrm{n}=102, H=$ 7.732, $\mathrm{p}=0.021)$; bluefish of intermediate length (151 to $200 \mathrm{~mm}$ ) had higher gut fullness values. Bluefish from the 2002 year-class had significant effects of length on gut fullness during November ( $\mathrm{df}=2, \mathrm{n}=$ 114, $H=6.997, \mathrm{p}=0.030$ ) and marginally significant effects during December $(\mathrm{df}=2, \mathrm{n}=95, H=5.651, \mathrm{p}=$ 0.059); median gut fullness values increased with increasing length for each month.

\section{Negative size-selective mortality}

Negative size-selective overwinter mortality was evident for Cohort 3 during the winter of 2002 to 2003. The mean length of trawl-caught fish increased significantly from 146.6 to $157.5 \mathrm{~mm}(t=7.699$, df $=455, \mathrm{p}<$ $0.001)$, variance decreased $(F=2.315$, df $=455, \mathrm{p}<$ 0.001 ), and the coefficient of variation decreased from 8.71 to 5.33 between December 2002 and April 2003 (Fig. 4c,e).

\section{DISCUSSION}

\section{Temporal abundance and cohort structure}

This study has shown coastal Onslow Bay to be an important overwintering area for juvenile bluefish. However, temporal patterns in CPUE suggest that winter severity affects nearshore abundance in Onslow Bay. During the milder winter of 2001 to 2002, bluefish were caught during every month with the exception of March. However, during the more severe winter of 2002 to 2003 only 1 bluefish (trawl) was caught during the months of January through March. Further, there is evidence that the preferred overwintering temperature increases with increasing bluefish size. This may be due to increasing tolerance of acute cold stress with decreasing length. Slater et al. (2007) held YOY bluefish in outdoor tanks at ambient temperatures during the winter and found Cohort 2 to be more tolerant of acute cold stress mortality than Cohort 1. Increasing cold tolerance with decreasing length has also been shown for Atlantic croaker (Lankford \& Targett 2001). Few members of Cohort 1 were caught in nearshore waters of Onslow Bay once temperatures dropped below $16^{\circ} \mathrm{C}$. The third cohort
Fig. 8. Pomatomus saltatrix. Mean $( \pm \mathrm{SE})$ monthly gut fullness index for YOY captured by bottom trawl in Onslow Bay, along with mean daily water temperature for (a) the 2001 year-class, and (b) the 2002 year-class. Note separate $y$-axis for each variable 
may be the most tolerant of low temperatures as it was typically the only cohort caught in large numbers when temperature dropped below $13^{\circ} \mathrm{C}$. The energetic cost of migrating to warmer areas may be too great for smaller bluefish; they may instead remain in cooler water to suppress metabolic rates and minimize energy loss. Therefore the overwintering distribution for YOY bluefish may depend on body size.

The decreases in abundance of each cohort as temperature drops may be the result of an offshore or a southward migration. Offshore migration probably plays a critical role, as the proximity of the Gulf Stream creates a strong temperature gradient on the continental shelf in the SAB. Further, nearshore waters to the south of Onslow Bay during the winter months have similar or lower temperatures than southern North Carolina (Atkinson et al. 1983). On January 22, 2003, the US Fish and Wildlife Service collected members of Cohorts 1 and $2(n=8)$ in waters to the north of our sampling area where the influence of the Gulf Stream is stronger (Fig. 4d). This was during the most severe part of the winter in our sampling area when temperatures fell below $9^{\circ} \mathrm{C}$ and only one bluefish was caught during adjacent sampling periods (Fig. 2b). Despite this evidence, for each year-class, no bluefish (trawl) were captured in March despite suitable temperatures. This may be due to bluefish selecting warmer temperatures further from shore as the winter ends, or the result of a southward component to winter migration, which delays their return to Onslow Bay.

The present study has provided support for a growing consensus of more complicated recruitment patterns in YOY bluefish than previously thought. When this study was initiated, length-frequency distributions of Age-0 bluefish had consistently been described as bimodal, consisting of spring- and summer-spawned bluefish (McBride \& Conover 1991, Munch \& Conover 2000). However, 3 recent studies have identified at least 3 cohorts of YOY bluefish (Able et al. 2003, Wilber et al. 2003, Taylor \& Able 2006). In the MAB these additional cohorts are likely the result of multiple peaks in summer-spawning activity (Taylor \& Able 2006).

It remains uncertain if the 3 cohorts observed in this study corresponded to those recently described in the MAB as spring, early-summer, and late-summer spawned (Wilber et al. 2003). Therefore, the 3 cohorts in the present study were labeled numerically. Two plausible scenarios of cohort structure for these data are apparent. The first scenario is that Cohort 3 was a late-summer cohort and the other 2 cohorts represented early-summer (Cohort 2) and spring-spawned (Cohort 1) bluefish, as has been described in the MAB (Wilber et al. 2003). The second scenario is that the late-summer cohort was not captured in the present study and that Cohort 3 was composed of summer- spawned individuals while the 2 larger cohorts were subcohorts of spring-spawned bluefish. Daily aging of YOY bluefish during the fall as well as estimating growth during fall months would aid in understanding cohort structure during the winter.

\section{Seasonal energy and feeding dynamics}

Larger juvenile bluefish possess an advantage in energy storage when entering winter. This increase in relative energy stores with increasing length is a common trend observed in fish during the fall (Schultz \& Conover 1997, Post \& Parkinson 2001, Hurst \& Conover 2003). The accumulation and subsequent depletion of energy stores in both muscle and liver tissue suggest both are important storage depots. Laboratory evidence also suggests white muscle and liver as important storage depots, along with viscera, red muscle, and skin (Slater et al. 2007). The seasonal patterns in energy storage are strongly affected by changes in lipid content, due to its high-energy value and seasonal variability. However, the importance of protein is also evident for bluefish by changes in liver protein allometries between months, which suggests mobilization of liver protein during the winter by larger fish. Liver protein has been shown to be an important source of energy reserves in other species (Black \& Love 1986). Further, lean tissue in striped bass has been shown to account for 36 to $66 \%$ of total energy lost during the winter (Hurst \& Conover 2003).

The observed size-based advantage in energy storage during the fall may be due to different allocation strategies for energy consumed, with smaller fish putting more energy into growth and larger fish storing energy. The reason for different allocation strategies may be the relative risks of predation mortality and starvation mortality during the winter (Post \& Parkinson 2001). Smaller individuals may gain a greater survival advantage in gaining size and becoming less vulnerable to predation (Sogard 1997). Conversely, larger individuals invoke an energy storage strategy for winter survival and apportion a greater amount of ingested energy to storage rather than growth.

While larger individuals had relatively greater energy stores in the fall, this energetic advantage declined during the winter because the rate of energy depletion increased with increasing bluefish length. These results are contradictory to prior observations in overwintering starvation experiments, whereby smaller fish exhausted their energy stores more rapidly than larger fish (Post \& Evans 1989, Schultz \& Conover 1999, Sogard \& Olla 2000). Further, overwintering field studies on striped bass (Hurst \& Conover 2003) and Atlantic silversides (Schultz \& Conover 1997) have 
found larger fish to have disproportionately greater energy stores throughout the overwintering period.

The unusual energy depletion patterns observed in our data are not likely to be an artifact of sampling different portions of the population each month, because similar energy depletion patterns were observed in a laboratory experiment when fish were fed (Slater et al. 2007). Slater et al. (2007) determined that while larger bluefish started the winter with more energy reserves, by early spring there was no difference in energy reserves between cohorts when food was provided. When starved, bluefish depleted energy at similar rates regardless of size (Slater et al. 2007).

There are 3 plausible mechanisms by which smaller bluefish may exhibit lower energy depletion rates. First, if smaller bluefish are depleting energy stores more slowly during the winter, a higher feeding rate may be expected to offset the higher metabolic needs of smaller fish (Post \& Lee 1996, Schultz \& Conover 1999). If this were the case, gut fullness should increase with decreasing length. However, the opposite trend was observed, with larger fish feeding more during 3 of the 4 mo examined. This is not surprising during the winter months examined as any size-based trends in energy storage had already disappeared. However, during the fall months examined, size-based differences in energy storage were the most pronounced.

It is possible that the small bluefish surviving in the spring were those individuals able to feed successfully during the winter, and that the overall mortality of smaller bluefish was high. If smaller bluefish with relatively low energy stores experienced a higher mortality rate, the rate of energy depletion in smaller fish would not seem as great. The pattern of smaller fish depleting energy more slowly has been observed in other systems. Eckmann (2004) observed this pattern in perch and found no evidence of negative sizeselective mortality, indicating that energy depletion rates were not an artifact of mortality. Paul et al. (1998) found smaller Alaskan Pacific herring to deplete energy more slowly, but it is unclear if this pattern was influenced by mortality, as evidence of negative sizeselective mortality was present (Foy \& Paul 1999).

The reason smaller bluefish do not exhibit increased feeding levels may also be due to sized-based winter migration strategies. Paul et al. (1998) examined overwintering Pacific herring and discussed the possibility of smaller individuals depleting less energy during the winter by limiting movement and remaining in cooler water than larger fish. Also, Atlantic salmon in the laboratory during winter months actively choose cooler temperatures (Morgan \& Metcalfe 2001) and experience a reduction in appetite despite conditions that would allow feeding and growth to occur (Metcalfe \& Thorpe 1992). We suggest that larger YOY bluefish may inhabit warmer areas during the winter while smaller fish remain in cooler waters and experience lower rates of feeding and energy depletion. Further, larger bluefish may undertake more extensive winter migrations, which would require more energy reserves at the onset of winter and a greater energy depletion rate as winter progressed.

\section{Overwinter mortality}

Our results do not support the hypothesis that summer-spawned bluefish contribute little to the adult population. Evidence for negative size-selective mortality of Cohort 3 was found during the more severe winter of 2002 to 2003, but it did not occur at a great enough magnitude to eliminate the entire cohort. The presence of Cohorts 2 and 3 during the spring of both years suggests that relatively small bluefish do survive the winter. Also, based on comparison with a laboratory starvation experiment, small bluefish collected in the wild never approached critical energy reserves associated with mortality (Slater et al. 2007). Further, summer-spawned bluefish (Cohort 2) displayed over $90 \%$ survival after 4 mo in the laboratory without food (Slater et al. 2007). However, the magnitude of overwinter mortality in the field remains uncertain because no single cohort was captured consistently enough to estimate winter mortality rates using catch curve analysis.

It is unlikely that the increase in mean length and decrease in variation of Cohort 3 from late-fall 2002 to early spring 2003 was due to growth, since there was not an increase in the right tail of the length distribution. Further, the lower end of the distribution increased by around $25 \mathrm{~mm}$, and it is unlikely that these smaller fish grew during such a severe winter. Other studies that have examined negative size-selective mortality were conducted in more closed systems that limited the possibility of migration, thus biasing results. It is possible that the negative size-selective mortality observed in the present study was due to size-based migration into Onslow Bay. Also, the smaller bluefish from Cohort 3 may have utilized habitats closer to shore than those we sampled during the spring.

Temperature differences between the 2 winter seasons provided an opportunity to examine how winter severity may affect juvenile bluefish overwinter survival. The effects of the harsher winter of 2002 to 2003 on juvenile bluefish can be seen in a number of ways. There was a sharp decline in water temperature from November to December 2002, which was not observed during 2001. This sharp decline may have led to the lower energy reserves observed during the fall for the 2002 year-class. Further, given their extended absence from Onslow Bay 
during the more severe winter, juvenile bluefish may migrate greater distances to avoid stressful temperatures during harsh winters. A more extensive migration may involve greater energetic costs. Bluefish following the more severe winter of 2002 to 2003 had significantly lower liver and muscle energy stores than the preceding year-class. Last, the greater winter energy deficit experienced by the 2002 year-class may have influenced mortality. Winter severity has been shown to be an important factor in survival of YOY of other species including brook trout (Hunt 1969) and striped bass (Hurst \& Conover 1998). The influence of winter severity on YOY bluefish survival has yet to be examined.

\section{Implications}

To our knowledge this is the first overwintering field study to examine a species with the migratory capabilities of bluefish. Previous studies have examined closed systems or species that are restricted to a much smaller latitudinal range during the winter. We provide evidence that overwinter mortality in juvenile bluefish exerts a selective pressure, despite their ability to migrate to warmer areas during the winter season. This is evident in the seasonal build up and depletion of energy reserves during the overwinter period. The added energetic cost of migration in bluefish likely influences the need for increased energy storage prior to the winter season. Moreover, prey abundance has been shown to decline during the winter months off North Carolina (Morley 2004). Reduced prey abundance coupled with low temperatures inhibiting feeding likely prevent overwintering bluefish from meeting energetic demand. Consequently, bluefish depend on energy reserves to survive the winter. However, many aspects of the overwinter ecology of bluefish remain uncertain. We were unable to capture large numbers of each cohort throughout the overwintering period and the range and distribution of each cohort in the SAB during the winter has not been examined. In order to better understand the magnitude and dynamics of overwinter mortality additional effort is required including sampling areas extending over a greater portion of the SAB.

It has been suggested that only spring spawned bluefish be considered when quantifying juvenile abundance for recruitment indices (Conover et al. 2003). Based on catches of small bluefish following the winter season, our results do not support this suggestion. While negative size-selective mortality may occur in juvenile bluefish, it is not a suitable explanation for the unimodal back-calculated Age-1 length distributions observed in previous studies (Chiarella \& Conover 1990, Conover et al. 2003). Our work has shown that bluefish recruitment is more complex than previously thought. In order to assess the relative contribution of each cohort to the adult population, cohort structure of YOY bluefish needs to be more clearly understood to interpret back-calculated Age-1 length distributions.

Acknowledgements. We thank the bluefish/striped bass dynamics research program sponsored by Rutgers University and NMFS for funding the project. We are grateful for the hard work by the captains and crew of the RV 'Cape Fear' out of UNC-Wilmington: D. Aspenleiter, M. Rodaway, C. Ruch, and K. Johns. P. Rudershausen, J. Arnott, M. Williams, M. May, J. Slater, C. Yoder, N. Bacheler, and C. Taylor aided in field collections and laboratory work. B. Degan provided samples from the US Fish and Wildlife Service winter tagging cruise. P. Whitfield provided temperature logger data. J. Rice, L. Stefanski, and M. Wuenschel reviewed the manuscript.

\section{LITERATURE CITED}

Able KW, Rowe P, Burlas M, Byrne D (2003) Use of ocean and estuarine habitats by young-of-the-year bluefish (Pomatomus saltatrix) in the New York Bight. Fish Bull 101:201-214

Adams SM, McLean RB, Huffman MM (1982) Structuring of a predator population through temperature-mediated effects on prey availability. Can J Fish Aquat Sci 39:1175-1184

Anonymous (2000) SEAMAP-SA 10-year trawl report: results of trawling efforts in the coastal habitat of the South Atlantic Bight, FY 1990-1999. Atlantic States Marine Fisheries Commission Report No. 71, South Carolina Department of Natural Resources, Charleston, SC

Atkinson LP, Lee TN, Blanton JO, Chandler WS (1983) Climatology of the southeastern United States continental shelf waters. J Geophys Res 88:4705-4718

Barger LE (1990) Age and growth of bluefish Pomatomus saltatrix from the northern Gulf of Mexico and U.S. south Atlantic coast. Fish Bull 88:805-809

Bhattacharya CG (1967) A simple method of resolution of a distribution into Gaussian components. Biometrics 23: 115-135

Black D, Love RM (1986) The sequential mobilization and restoration of energy reserves in tissues of Atlantic cod during starvation and refeeding. J Comp Physiol B 156:469-479

Brett JR, Groves TDD (1979) Physiological energetics. In: Hoar WS, Randall DJ, Brett JR (eds) Fish physiology, Vol 8. Academic Press, New York, p 279-352

Carmichael JT, Burns BL, Gregory RW (2002) Comparison of age assignment and reader agreement for bluefish (Pomatomus saltatrix) based on scales, whole otoliths, and sectioned otoliths. NC Division of Marine Fisheries, Morehead City, NC

Chiarella LA, Conover DO (1990) Spawning season and firstyear growth of adult bluefish from the New York Bight. Trans Am Fish Soc 119:455-462

Conover DO, Ross MR (1982) Patterns in seasonal abundance, growth, and biomass of the Atlantic silverside, Menidia menidia, in a New England estuary. Estuaries 5:275-286

Conover DO, Gilmore T, Munch SB (2003) Estimating the relative contribution of spring- and summer-spawned cohorts to the Atlantic coast bluefish stock. Trans Am Fish Soc 132:1117-1124

Cunjak RA, Curry RA, Power G (1987) Seasonal energy budget of brook trout in streams: implications of a possible deficit in early winter. Trans Am Fish Soc 116:817-828 
Eckmann R (2004) Overwinter changes in mass and lipid content of Perca fluviatilis and Gymnocephalus cernuus. J Fish Biol 65:1498-1511

Fahay MP, Berrien PL, Johnson DL, Morse WW (1999) Essential fish habitat source document: bluefish, Pomatomus saltatrix, life history and habitat characteristics. NOAA Tech Mem NMFS-NE-144:68

Foltz JW, Norden CR (1977) Seasonal changes in food consumption and energy content of smelt (Osmerus mordax) in Lake Michigan. Trans Am Fish Soc 106:230-234

Foy RJ, Paul AJ (1999) Winter feeding and changes in somatic energy content of age-0 Pacific herring in Prince William Sound, Alaska. Trans Am Fish Soc 128:1193-1200

Gayanilo FC Jr, Sparre P, Pauly D (2002) FAO-ICLARM stock assessment tools II (FiSAT II). User's guide, FAO Computerised information series No. 8, rev. FAO, Rome

Griffiths D, Kirkwood RC (1995) Seasonal variation in growth, mortality and fat stores of roach and perch in Lough Neagh, Northern Ireland. J Fish Biol 47:537-554

Hare JA, Cowen RK (1996) Transport mechanisms of larval and pelagic juvenile bluefish (Pomatomus saltatrix) from South Atlantic Bight spawning grounds to Middle Atlantic Bight nursery habitats. Limnol Oceanogr 41:1264-1280

Hasselblad V (1966) Estimation of parameters for a mixture of normal distribution. Technometrics 8:431-444

Hunt RL (1969) Overwinter survival of wild fingerling brook trout in Lawrence Creek, Wisconsin. J Fish Res Board Can 26:1473-1483

Hurst TP, Conover DO (1998) Winter mortality of young-ofthe-year Hudson River striped bass (Morone saxatilis): size-dependent patterns and effects on recruitment. Can J Fish Aquat Sci 55:1122-1130

Hurst TP, Conover DO (2003) Seasonal and interannual variation in the allometry of energy allocation in juvenile striped bass. Ecology 84:3360-3369

Kendall AW, Walford LA (1979) Sources and distribution of bluefish, Pomatomus saltatrix, larvae and juveniles off the east coast of the United States. Fish Bull 77:213-227

Lankford TE, Targett TE (2001) Low temperature tolerance of age-0 Atlantic croaker: recruitment implications for U.S. Mid-Atlantic estuaries. Trans Am Fish Soc 130:236-249

Lassiter RR (1962) Life history aspects of the bluefish, Pomatomus saltatrix (Linnaeus), from the coast of North Carolina. MS thesis, North Carolina State University, Raleigh

Love RM (1980) The chemical biology of fishes, Vol 2. Academic Press, London

McBride RS, Conover DO (1991) Recruitment of young-ofthe-year bluefish, Pomatomus saltatrix, to the New York bight: variation in abundance and growth of spring- and summer-spawned cohorts. Mar Ecol Prog Ser 78:205-216

McBride RS, Ross JL, Conover DO (1993) Recruitment of bluefish (Pomatomus saltatrix) to the estuaries of the South Atlantic Bight. Fish Bull 91:389-395

Metcalfe NB, Thorpe JE (1992) Anorexia and defended energy levels in over-wintering juvenile salmon. J Anim Ecol 61:175-181

Miranda LE, Hubbard WD (1994) Length-dependent winter survival and lipid composition of age-0 largemouth bass in Bay Springs Reservoir, Mississippi. Trans Am Fish Soc 123:80-87

Morgan IJ, Metcalfe NB (2001) The influence of energetic requirements on the preferred temperature of overwintering juvenile Atlantic salmon (Salmo salar). Can J Fish Aquat Sci 58:762-768

Morley JW (2004) Ecology of juvenile bluefish (Pomatomus saltatrix) overwintering off North Carolina. MS thesis, North Carolina State University, Raleigh, NC
Munch SB (1997) Recruitment dynamics of bluefish, Pomatomus saltatrix, on the continental shelf from Cape Fear to Cape Cod, 1973-1995. MS thesis, State University of New York, Stony Brook, NY

Munch SB, Conover DO (2000) Recruitment dynamics of bluefish (Pomatomus saltatrix) from Cape Hatteras to Cape Cod, 1973-1995. ICES J Mar Sci 57:393-402

NOAA Fisheries (2005) MRFSS time series query. www.st.

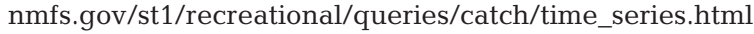

Oliver JD, Holeton GF, Chua KE (1979) Overwinter mortality of fingerling smallmouth bass in relation to size, relative energy stores, and environmental temperature. Trans Am Fish Soc 108:130-136

Paul AJ, Paul JM, Brown ED (1998) Fall and spring somatic energy content of Alaskan Pacific herring (Clupea pallasi Valenciennes 1847) relative to age, size and sex. J Exp Mar Biol Ecol 223:133-142

Post JR, Evans DO (1989) Size-dependent overwinter mortality of young-of-the-year yellow perch (Perca falvescens): laboratory, in situ enclosure, and field experiments. Can J Fish Aquat Sci 46:1958-1968

Post JR, Lee JA (1996) Metabolic ontogeny of teleost fishes. Can J Aquat Sci 53:910-923

Post JR, Parkinson EA (2001) Energy allocation strategy in young fish: allometry and survival. Ecology 82:1040-1051

Ricker WE (1969) Effects of size-selective mortality and sampling bias on estimates of growth, mortality, production, and yield. J Fish Res Board Can 26:479-541

Salerno DJ, Burnett J, Ibara RM (2001) Age, growth, maturity, and spatial distribution of bluefish, Pomatomus saltatrix (Linnaeus), off the northeast coast of the United States, 1985-96. J Northw Atl Fish Sci 29:31-39

Schultz ET, Conover DO (1997) Latitudinal differences in somatic energy storage: adaptive response to seasonality in an estuarine fish (Atherinidae: Menidia menidia). Oecologia 109:516-529

Schultz ET, Conover DO (1999) The allometry of energy reserve depletion: test of a mechanism for a size dependent winter mortality. Oecologia 119:474-483

Sipe AM, Chittenden ME (2002) A comparison of calcified structures for aging bluefish in the Chesapeake Bay region. Trans Am Fish Soc 131:783-790

Slater JJ, Lankford TE, Buckel JA (2007) Overwintering ability of young-of-the-year bluefish (Pomatomus saltatrix): effects of ration and cohort of origin on survival. Mar Ecol Prog Ser (in press)

Smith W, Berrien P, Potthoff T (1994) Spawning patterns of bluefish, Pomatomus saltatrix, in the northeast continental shelf ecosystem. Bull Mar Sci 54:8-16

Sogard SM (1997) Size-selective mortality in the juvenile stage of teleost fishes: a review. Bull Mar Sci 60:1129-1157

Sogard SM, Olla BL (2000) Endurance of simulated winter conditions by age- 0 walleye pollock: effects of body size, water temperature and energy stores. J Fish Biol 56:1-21

StatSoft (2004) Statistica Version 6.1. StatSoft, Tulsa, OK

Sutton TM, Ney JJ (2001) Size-dependent mechanisms influencing first-year growth and winter survival of stocked striped bass in a Virginia mainstream reservoir. Trans Am Fish Soc 130:1-17

Taylor DL, Able KW (2006) Cohort dynamics of summerspawned bluefish as determined by length-frequency and otolith microstructure analyses. Trans Am Fish Soc 135:955-969

Wilber DH, Clarke DG, Burlas MH, Ruben H, Will RJ (2003) Spatial and temporal variability in surf zone fish assemblages on the coast of northern New Jersey. Estuar Coast Shelf Sci 56:291-304

Submitted: February 5, 2005; Accepted: June 23, 2006

Proofs received from author(s): March 19, 2007 